\title{
パルス通電加圧焼結法におけるモールドと試料の温度測定
}

\author{
琶見 新一, 水谷 芳樹, 米谷 道夫 \\ 東北工業技術研究所，＝983-0036 仙台市宮城野区苦竹 4-2-1。
}

\section{Temperature Measurement of the Mold and Samples on the Pluse Plasma Sintering}

\author{
Shin-ichi Sumi, Yoshiki Mizutani and Michio Yoneya \\ Tohoku National Industrial Research Institute, 4-2-1 Nigatake Miyagino-ku, Sendai 983-0036.
}

Received July 7, 1997

\begin{abstract}
SYNOPSIS
The plasma activated sintering (PAS) is a kind of hot pressing method. During pressing, the electric current flows in the mold (die and punches) and powder sample. There are two types of electric current. The surface of the powder is cleaned and activated by activating electric current. The mold and powder sample is heated by sintering electric current due to the Joule effect. It is well-known that the temperature of a sample is closely related to the sintered materials' properties and there is a favored temperature for sintering the powder. The temperature is measured either by thermocouples in the mold or by an infrared optical thermometer focused on the mold surface, but these measurements do not give the temperature of the sample in the mold itself. Sometimes the real temperature of samples is higher than the measured temperature. This temperature difference depends on the material properties, especially the electric resistance and the thickness of the sample. The authors studied experimentally the relation between the temperature difference and the electric resistance using dummy samples made of stainless steel, graphite and alumina.
\end{abstract}

KEY WORDS

plasma activated sintering, mold, graphite, alumina, powder

\section{1 緒言}

新しい焼結法として注目されているパルス通電加圧(放電プ ラズマ)焼結法は，直接通電焼結法の一種である．活性化電流 と呼ばれている数 $10 \mathrm{~Hz}$ のパルス電流を数 $10 \mathrm{~s}$ 通電することに より，粉体試料の表面が清浄化され，活性化される，その後， 特殊 (焼結) 電流と呼ばれている $300 \mathrm{~Hz}$ 程度のノコギリ波を重 畺した直流を通電することによって,試料はジュール熱で加熱 され，焼結される．その熱は粉末試料，上下部パンチあるいは ダイからの発熱に起因している. 焼結温度は，ダイ表面または ダイ中の温度によって制御されている。しかし，試料とダイの 温度には差があり，試料の組成や厚さなどによっても，その温 度差が変化する。このことが本法による安定な焼結体の作製を 阻害しており，重要な問題となっている(1)．これらの問題を 解決するため，異なった比抵抗を持つステンレス鋼，グラファ イトおよびアルミナ試料を使って，モールド(ダイ拉よび上下
部パンチ)中およびその表面の温度分布測定など, 実験的な検 討を行ったので報告する.

\section{2 実験方法}

2.1 試料中心部とダイ内の温度分布測定 パルス通電加圧焼結機(ソディック(侏製 PAS-V-1 型)の焼結 温度は, 約1300K以下ではダイにあけた細孔内に装填したシー ス型熱電対で，それ以上の温度ではダイ表面に焦点を合わせた 放射温度計で測定された值で制御されている。焼結時の粉末試 料の温度を直接測定することは困難であるので, 試料と夕゙イの 温度差を調べる目的で，比抵抗の異なる材料を焼結体の形状に 加工したステンレス鋼(SUS304), グラファイトおよびアルミナ 製のダミ一試料を使用した. 前者の 2 試料は, 固体から所定の 大きさに成形し,アルミナ試料は, 平均粒径 $20 \mu \mathrm{m}$ の粉末 (関 東化学(㑣製)を50MPaで圧粉して成形したものを使用した。 こ 
れら試料の中心部までの細孔(深さ $25 \mathrm{~mm}$ ) と，グラファイト 製ダイ表面から深さ3，6，9，12，15mmの細孔をあけ，そこに インコネル製シース型熱電対を挿入して温度測定を行った。

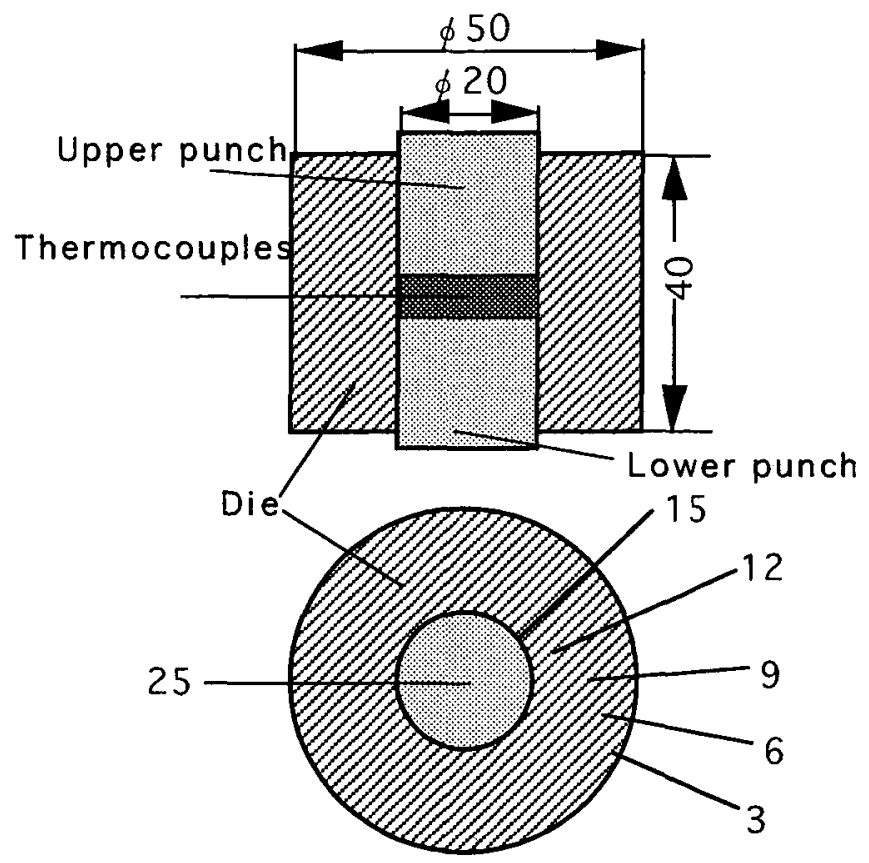

Depth from die surface $(\mathrm{mm})$

Fig.1 Concept of temperature measurement in the graphite die.

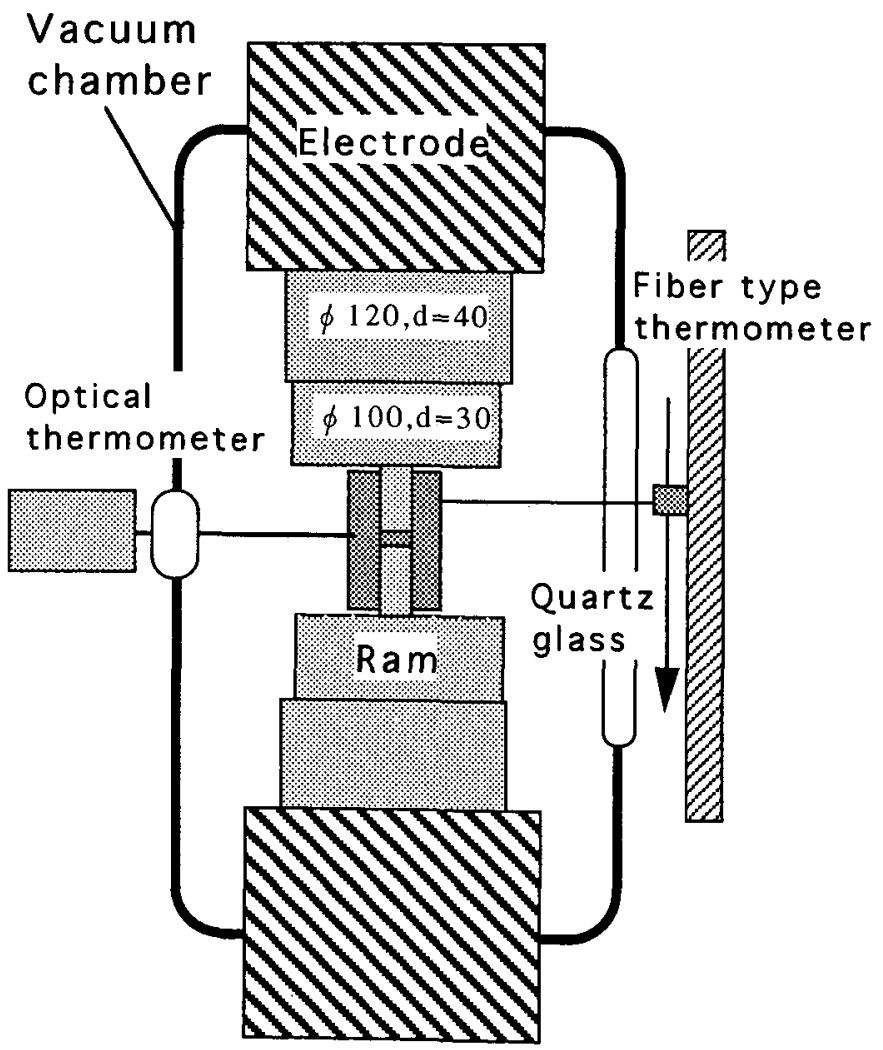

Fig.2 Concept of temperature measurement on the mold surface.
熱電対の配置図を Fig.1に示す．深さ $3 \mathrm{~mm}$ から $15 \mathrm{~mm}$ の細孔 は,ダイの中央に角度約 $0.5 \mathrm{rad}$ の範囲内に扇状に配置した。中 心部に挿入した熱電対は，ある程度の強度が必要なため直径 $1.6 \mathrm{~mm}$ を，ダイに聥入した熱電対は，それ自身の熱容量を小 さくするため直径 $0.6 \mathrm{~mm}$ を使用した、シース材料の耐熱温度 やグラファイトとの反応性の制約から $1300 \mathrm{~K}$ 以下で実験を行 い，焼結中にダイ中のそれぞれの深さの温度と試料中心部の 温度を20s 毎に記録した。

\section{2 モールド表面の温度分布測定}

本法で焼結する際に上下部パンチが高温になる場合があり， それを定量的に把握するため，モールド表面温度の測定を 行った. 温度計はファイバー型放射温度計(ジャパンセンサー (侏)製 FTZ2-P400-50S-12 型) を使用した。この温度計の測定距 離は， $500 \mathrm{~mm}$ であり，測定標的サイズは直径 $3 \mathrm{~mm}$ である。 Fig.2に示すように焼結機の前面の屝部分に $20 \times 200 \mathrm{~mm}$ の石 英ガラスの空を作り，真空チャンバーの外部からモールド表 面の温度を走查して測定できるように設計した. 温度制御は, ダイ表面の温度を別の放射温度計で測定し，その值で行った。 測定温度は 1073, 1273, 1473Kの3ステップで行い，それぞれ の温度が平衡に達した時に測定を開始し，走查間隔は $5 \mathrm{~mm}$ と し，上部ラムから下部ラムに掛かるまで測定した。 また，こ

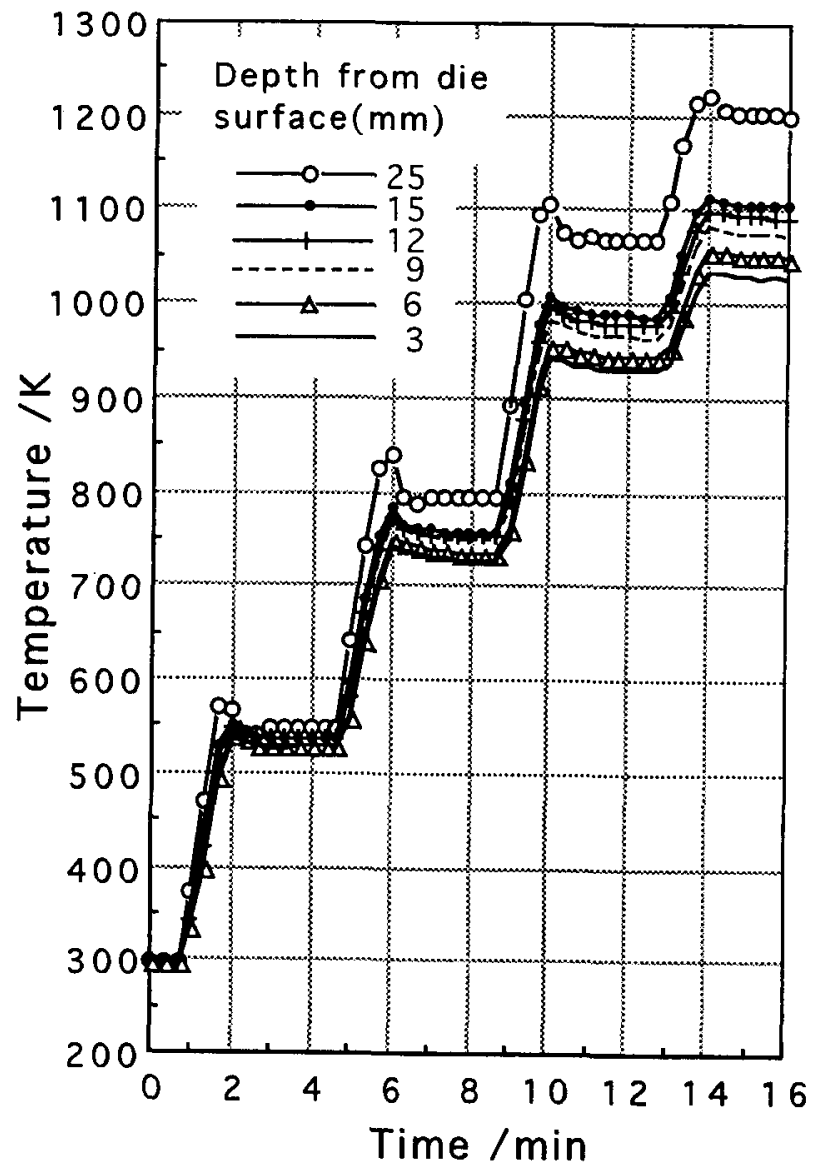

Fig.3 Temperature variation of graphite sample at different depth in the mold. 
の測定では，測定標的サイズを確保するため通常より $10 \mathrm{~mm}$ 長い, 30mmのパンチを使用した。

\section{3 実験結果および考察}

3.1 試料中心部とダイ内の温度分布について

厚さ $6 \mathrm{~mm}$ のグラファイト試料を使用し,ダイ表面から深さ $3 \mathrm{~mm}$ の位置で測定した温度值を使って焼結温度を制御した場 合の，試料とダイの各深さでの温度測定結果を Fig. 3 に示す. 測定は, $2 \mathrm{~Pa}$ 真空度で, 設定温度を4ステップ $(523,723,923$, $1023 \mathrm{~K})$ に変化させ，それぞれの深さでの温度を測定した。な お，活性化電流の通電時間は30s，パルスタイムは $3 \times 10^{-2} \mathrm{~s}$ (パ ルス幅は $17 \mathrm{~Hz}$ )である. Fig. 3 に示すように深さ $3 \mathrm{~mm}$ の温度 は，良く制御されているが，深さ $25 \mathrm{~mm}$ (試料中心)の温度は， 温度設定の変更に伴い, 約 $50 \mathrm{~K}$ のオーバーシュートが起きて いる。この昇温速度は $3.3 \mathrm{~K} / \mathrm{s}$ であり，昇温速度によっては， このような現象が生じることに留意する必要がある.同様の 測定をステンレス鋼とアルミナ試料について行い，それらの 平衡時における各深さでの温度測定結果を Fig.4の (a), (b), (c) に示す。ダイ中の温度勾配は，深さに対して，ほほ直線的 に変化しており,同じ設定温度ではアルミナ,グラファイト， ステンレス鋼試料の順で小さくなっている，また，その温度 勾配は，設定温度が高くなるに従い，大きくなっている。こ れはダイ表面からの輻射が表面温度の 4 乗に比例するためで
ある。

グラファイトとステンレス鋼試料においては,試料の中心 温度が，ダイ中の温度勾配の延長線上に一致している。 た,アルミナ試料では, 試料の外周部(深さ $15 \mathrm{~mm}$ )の温度が 高く，中心部の温度が低くなっている。これらことは，試料 の比抵抗の差に起因しており，文献値ではステンレス鋼，グ

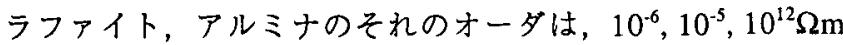
である.ダイの材料であるグラファイトより非常に比抵抗の 大きいアルミナ試料では，上部パンチを通った焼結電流が試 料の外側のダイにほとんど流れ，その後，下部パンチに流れ るため, 試料外周部の温度が高くなる。一方，ダイと同質材 料であるグラファイト試料では, 上部パンチからの焼結電流 は試料を通って下部パンチに流れており, 試料が発熱する. その際,ダイにどの程度に電流が流れているかについては， この実験結果からは不明である.中居らのシミュレーション 結果では，パルス電流の立ち上がり，平衡部，立ち下がりに よって,電流のモールド内を流れる経路が決まるとの報告が ある ${ }^{8)}$.

ダイ中の温度分布から発熱している部分を考察するため， Fig.4の (b) と (c) の結果を使って, 深さ $15 \mathrm{~mm}$ (ダイと試料の 界面) から深さ $3 \mathrm{~mm}$ までの温度分布ついて検討した結果を Fig.5の (a), (b)に示した. ダイの形状をした中空円柱体におい て, 媣さ $3 \mathrm{~mm}$ から $15 \mathrm{~mm}$ までの温度が平衡に達している時の，

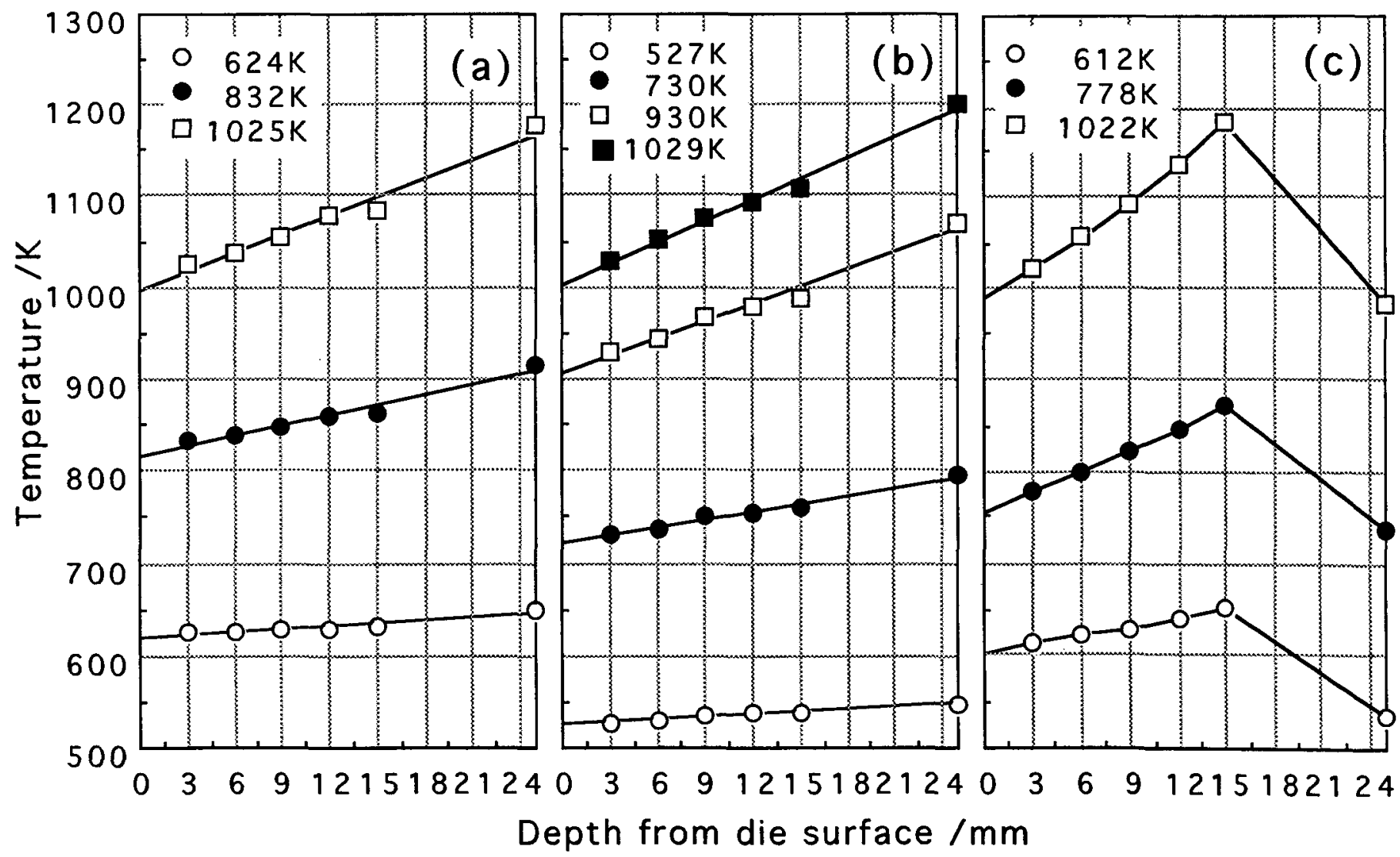

Fig.4 Temperature at the different depth from the die surface, (a): stainless steel, (b): graphite, (c): alumina. 


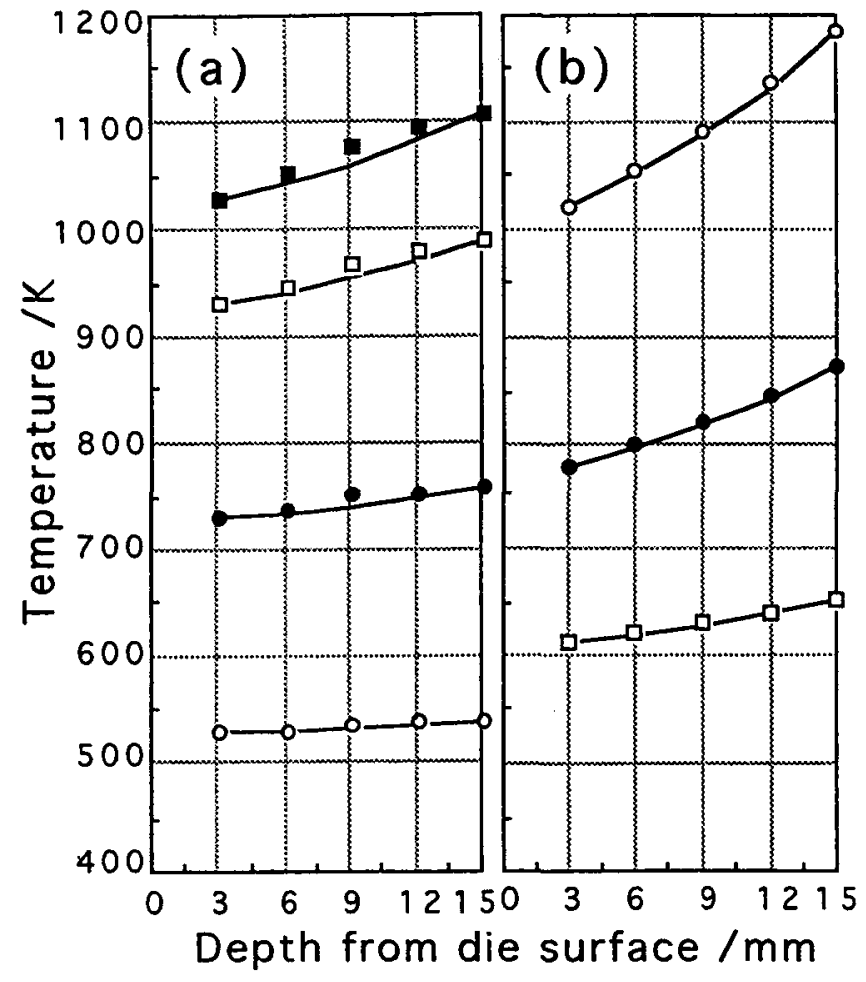

Fig.5 Measured and calculated temperature, (a):graphite sample, (b):alumina sample, dots:measured, line:calculated.

その間の温度変化を熱伝導問題 ${ }^{\text {Appendix) }}$ として計算した結果を 図中に実線で示した. Fig.5(b)のアルミナ試料では, 測定値と 計算値が良く一致していることから，発熱部は試料に接する ダイ側であり，他からの熱の供給がほとんどないと考えられ る.一方, Fig.5(a)のグラファイト試料では，試料自身が発熱 するが, 深さ 15 から $3 \mathrm{~mm}$ 間のダイ温度が計算值より高くなっ ているとのから，後述するように高温になっているパンチか らの熱供給もあると考えられる。

\section{2 モールド表面の温度分布について}

厚さ $6 \mathrm{~mm}$ のグラファイトとアルミナ試料を使い, 測定した 結果を Fig.6に示す.図の上部には，測定位置に対応するラム， ダイおよびパンチを図示した. グラファイト，アルミナの両 試料ともダイ表面の中央部と端部の温度差は, 数 $\mathrm{K}$ 程度で あった，一方，パンチ部分はダイ表面より高温になっており， グラファイト試料では，その温度差が各温度ステップのそれ ぞれで80,200,400Kになっており，アルミナ試料のそれらは, 0,70,330Kであり，グラファイト試料の方がパンチ温度がよ り高くなっていた，パンチの温度は焼結電流の大きさに相関 しており，パンチの長さが同じであるので，グラファイト試 料の方がより大きな焼結電流が流れていることを示している.

$$
4 \text { まと め }
$$

パルス放電加圧焼結法における試料とダイの温度には差に

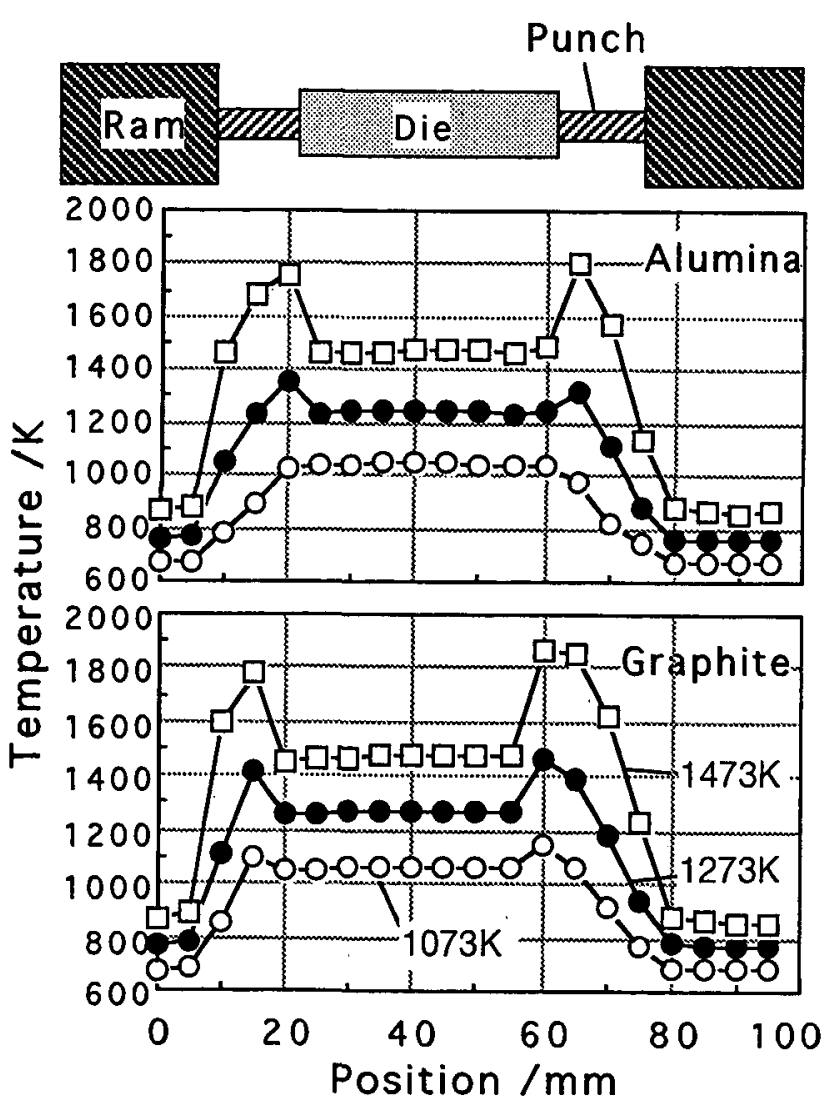

Fig.6 Measured temperature on the mold surface.

ついて，異なった比抵抗を持つステンレス鋼，ダラファイト およびアルミナ試料を使って，モールド中およびその表面の 温度分布測定など, 実験的な検討を行った。おもな結果は, 以 下の通りである。

(1) 昇温速度によっては, 試料温度が平衡に達する前に, 試料 温度が一時的に高くなることがある。

(2) ダイ中の温度勾配は, 深さに対して, ほぼ直線的に変化し ており，それはアルミナ，グラファイト，ステンレス鋼試 料の順で小さくなっていた，その温度勾配は, 温度が高く なるに従い, 大きくなっている。これはダイ表面からの輻 射が表面温度の 4 乗に比例するためである.

(3) グラファイトとステンレス鋼試料において,試料の中心温 度が，ダイ中の温度勾配の延長線上に一致していた。ま た，アルミナ試料では，試料外周部の温度が高く，中心部 が低くなっていた.これらのことは, 試料の比抵抗の差に 起因していると考えられる。

(4) グラファイト,アルミナ試料ともダイ表面の中央部と端部 の温度差は，ほとんどなかった。一方，パンチ部分は，グ ラファイト試料の方がより高温になっており，より大きな 焼結電流が流れていることを示している。

(5) 平衡状態のダイ中の温度分布を, 熱伝導問題として計算 
した。アルミナ試料では，測定值と計算值が良く一致し ていることから，他からの熱の供給がほとんどないと考 えられ，グラファイト試料では, 計算值よりダイ中の温 度が高くなっており,パンチからの伝熱があると考えら れる。

本研究の最終的な目標は，これらの実験結果を基に合理的 な仮定や境界条件を設定し，数值解析によって試料温度を推 定することであり，そのために必要な実験をさらに実施して いる.

\section{文献}

1) 熟見新一: 平成 8 年度金研共同利用ワークショップ「放電 プラズマ焼結」講演要旨集,(1996)5

2) 釜井正善, 木下秀一, 大前暢, 節原裕一, 三宅正司 : 平成 8 年度金研共同利用ワークショップ「放電プラズマ焼結」 講演要旨集 , (1996)10.

3）驾見新一,水谷芳樹, 增田善雄, 米谷道夫: 1996年東北工 業技術研究所研究発表会講演要旨集, (1996)41.

4) 長柄毅一，野瀬正照，横田勝：粉体および粉末治金, 43(1996)1193.

5)内野克哉, 池ヶ谷明彦, 野村俊雄, 宮川亜夫, 金田英伯: 粉 体㧍よび粉末治金, 43(1996)472.

6) 内野克哉, 池ヶ谷明彦, 宮川垔夫, 金田英伯：粉体および 粉末治金, 44(1997)269.

7)厳泰永，朴容浩，橋本等，見新一，阿部利彦, 渡辺龍三： 粉体および粉末治金, 44(1997)530.

8) 中居倫夫, 坂真澄, 阿部博之: 日本金属学会東北支部第 31 期講演会講演論文集, 961-1, (1996)31.

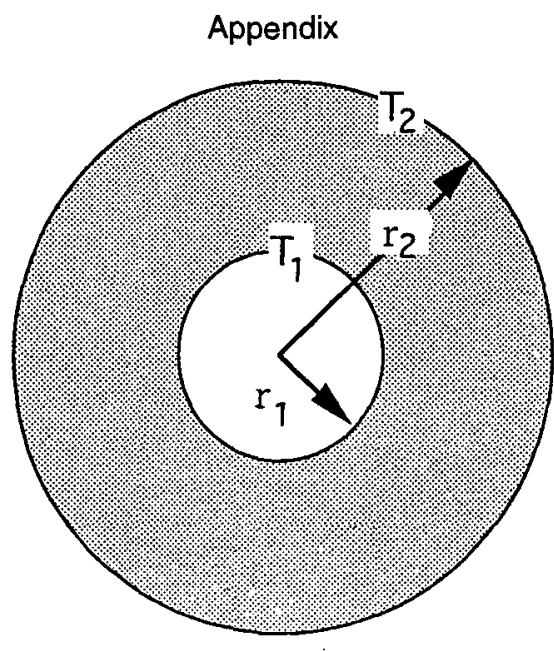

上の円筒座標での熱伝導は,

$$
q=-\lambda(2 \pi L) \frac{d T}{d r}
$$

$\mathrm{q}$ は熱流速， $\lambda$ は熱伝導率，Lは円筒の長さ，rは中心から の距離, $\mathrm{T}$ は温度

$$
\mathrm{q}\left(\frac{\mathrm{dr}}{\mathrm{I}}\right)=-\lambda(2 \pi \mathrm{L}) \mathrm{dT}
$$

$\mathrm{r}_{1}$ から $\mathrm{r}_{2}, \mathrm{~T}_{1}$ から $\mathrm{T}_{2}$ まで積分して

$$
\begin{aligned}
& \text { qIn }\left(\frac{\mathrm{r}_{2}}{\mathrm{r}_{1}}\right)=\lambda(2 \pi \mathrm{L})\left(\mathrm{T}_{1}-\mathrm{T}_{2}\right) \\
& \mathrm{T}_{2}=\mathrm{T}_{1}-\frac{\mathrm{q}}{\lambda(2 \pi \mathrm{L})} \ln \left(\frac{\mathrm{r}_{2}}{\mathrm{r}_{1}}\right)
\end{aligned}
$$

ここで $\mathrm{T}_{1}$ と $\mathrm{T}_{2}, \mathrm{r}_{1}$ と $\mathrm{r}_{2}$ をえると中心から任意の距離 $\mathrm{r}$ での 温度 Tを求めることができる。 